\title{
The elemental composition of garlic (Allium sativum $L$.) and its variability
}

\author{
Alexey Polyakov ${ }^{1,2, *}$, Tatyana Alekseeva ${ }^{1,2}$, Irina Muravieva ${ }^{2}$ \\ ${ }^{1}$ Moscow Region State University, 10A, Radio str., 105005, Moscow, Russia \\ ${ }^{2}$ All-Russian Research Institute of Vegetable Growing - FGBNU FNTSO branch, Vereya, b. 500, \\ Ramenskiy district, Moscow Region, 140153, Russia
}

\begin{abstract}
Garlic is a valuable source of macro- and microelements, especially potassium, calcium, magnesium, phosphorus, ferrum, manganese, selenium, vanadium, copper and zinc. In the dry substance of garlic there is about $4000 \mathrm{mg} / \mathrm{kg}$ of potassium $(48,1 \%$ from mass of all elements contained in cloves), about $1500 \mathrm{mg} / \mathrm{kg}$ of phosphorus $(18,3 \%)$, about $1400 \mathrm{mg} / \mathrm{kg}$ of sulphur (17,2\%), almost $900 \mathrm{mgs} / \mathrm{of} \mathrm{kg}$ of calcium $(10,7 \%)$, about $300 \mathrm{mg} / \mathrm{kg}$ of magnesium $(3,6 \%)$, about $100 \mathrm{mg} / \mathrm{of} \mathrm{kg}$ of natrium $(1,3 \%), 20 \mathrm{mg} / \mathrm{kg}(0,24 \%)$ of silicon, $16 \mathrm{mg} / \mathrm{kg}(0,20 \%)$ of ferrum, $14 \mathrm{mg} / \mathrm{kg}(0,17 \%)$ of zinc. The content of manganese, aluminum, copper and boron was in the range of $1.8 \mathrm{mg} / \mathrm{kg}(0.02 \%)-6.9 \mathrm{mg} / \mathrm{kg}(0.084 \%)$; chromium, nickel, selenium, cadmium, cobalt, iodine, lithium, vanadium, germanium, lead from $0.22 \mathrm{mg} / \mathrm{kg}(0.003 \%)$ to $0.013 \mathrm{mg} / \mathrm{kg}(0.0002 \%$; mercury $-0.0043 \mathrm{mg} / \mathrm{kg}(0.00005 \%)$. The cultivation of garlic in different climatic conditions leads to a significant change in the content of various elements. In this case, the content of vanadium, boron and cobalt can vary by 20 times, and the content of ferrum and germanium - more than 1000 times. The variability of the elemental composition of garlic depending on cultivar is much less than on the growing conditions. In general, the elemental composition, depending on cultivar, varies 1.1-4.7 times, and depending on the growing conditions, 2.1-57.4 times. Differences in changes in ferrum content depending on cultivar are 1.5 times, and depending on growing conditions - 57.4 times, respectively, copper 1.4 times and 54.0 times, sodium - 1.1 times and 26.8 times. Garlic is characterized by a unique elemental complex. According to indicators of sulfur, zinc, manganese and copper, it is approaching or corresponds to indicators of meat and fish. In this regard, it is necessary to use garlic more widely in the diet of vegetarians and diets that provide for limiting the consumption of meat and fish. It is necessary to develop technologies, methods, recipes that increase the consumption of garlic.
\end{abstract}

\section{Introduction}

Taking into account a decrease in the return of organic matter as manure, humus or compost to arable soil, a decrease in the content of various valuable elements in crop

\footnotetext{
* Corresponding author: kaf-bosh@mgou.ru
} 
production is observed. This is also due to the decrease of river spills, which has been observed in recent years. According to studies conducted at the RAMS Institute of Nutrition, the content of macronutrients in wheat over the thirty-year period has decreased significantly. This is especially true for calcium, magnesium and phosphorus. The concentration of these elements decreased by $37.0 \%, 21.2 \%$ and $18.6 \%$, respectively. Over this period, the content of these elements fell in beef by $20.0 \%, 5.9 \%$ and $16.7 \%$, moreover, the content of ferrum (35.9\%), vitamin A and riboflavin decreased sharply (Table 1). Unfortunately, there is no data regarding changes in the concentration of micronutrients. However, it can be assumed that the general trend will be similar or even more depressing due to the fact that most of the microlements do not return to the soil and are not replenished by fertilizers.

The mineral and organic composition of any plant product determines its nutritional value. The chemical elements obtained with food contribute to the normal functioning of the body. Their biological role is truly undeniable, they are part of various enzymes and hormones, participate in the regulation of important physiological functions. These functions are oxygen transport, maintaining osmotic pressure in the cells, proper development and functioning of muscles, teeth and bones [1-3].

Table 1. Reducing the content of chemical elements and nutrients in wheat and beef for the period from 1963 to 1992 (mg per $100 \mathrm{~g}$ ).

\begin{tabular}{|c|c|c|c|}
\hline Indicators & $\mathbf{1 9 6 3}$ & $\mathbf{1 9 9 2}$ & Change, \% \\
\hline \multicolumn{3}{|c|}{ Wheat } \\
\hline Calcium & 46 & 29 & -37.0 \\
\hline Phosphorus & 354 & 288 & -18.6 \\
\hline Ferrum & 3.40 & 3.19 & -6.2 \\
\hline Potassium & 370 & 363 & -1.9 \\
\hline Magnesium & 160 & 126 & -21.2 \\
\hline \multicolumn{4}{|c|}{ Beef } \\
\hline Calcium & 10 & 8 & -20.0 \\
\hline Phosphorus & 156 & 130 & -16.7 \\
\hline Ferrum & 2.70 & 1.73 & -35.9 \\
\hline Potassium & 236 & 228 & -3.4 \\
\hline Magnesium & & 16 & -5.9 \\
\hline Vitamin A, ME & 40 & 0 & -100.0 \\
\hline Thiamine & 0.080 & 0.038 & -52.5 \\
\hline Riboflavin & 0.160 & 0.151 & -5.6 \\
\hline Niacin & 4.30 & 4.48 & +4.2 \\
\hline
\end{tabular}

To date, about 70 elements are known that a human needs to fully function. The accumulation level of individual elements in plants depends on their content in the soil, the amount and form of fertilizer applied.

Garlic (Allium sativum L.) is an integral nutrition element of modern man. It significantly enhances the taste of prepared dishes, has a rich composition of organic and mineral substances, which allows possessing unique preventive and therapeutic properties regarding cardiovascular and oncological diseases.

Data on the content of individual elements in types of onion crops are rather scattered in literary sources, and for garlic in particular. Thus, it was determined that garlic oil contains as follows (mg/l): calcium - 6.77, phosphorus - 0.32, potassium - 62.22, magnesium - 27.6, manganese - 0.06, copper - 0.03 [3]. It was determined as well that garlic contains the following element quantities $(\mathrm{mg} / \mathrm{kg})$ : potassium - 546.5, calcium - 198.3, phosphorus 95.4, ferrum - 42.1, sodium - 41.0, magnesium 39.7, zinc - 3.4, manganese 0.16 and silver $0.012[4]$. 
B. J. Divya et al. (2017) [5] determined the content of several elements while studying the extract of garlic prepared using methanol. Those elements formed the following series: $\mathrm{K}>\mathrm{P}>\mathrm{Mg}>\mathrm{Ca}>\mathrm{Zn}>\mathrm{Al}$.

Turkish scientists [1] conducted a comparative analysis of the chemical composition for 88 garlic samples grown in 8 different regions of Turkey, regarding 11 following elements: $\mathrm{N}, \mathrm{P}, \mathrm{K}, \mathrm{Ca}, \mathrm{Mg}, \mathrm{S}, \mathrm{Zn}, \mathrm{Fe}, \mathrm{Mn}, \mathrm{B}, \mathrm{Na}$. As was noted, the content of the studied elements may differ significantly depending on the area of growth, or to be in close values as well. Thus, the magnesium content in the bulbs grown in the Kastamonu region was $65.4 \mathrm{mg} / \mathrm{kg}$, and for the Karaman region the value was $196.3 \mathrm{mg} / \mathrm{kg}$.

\section{Materials and methods of the research}

The studies were conducted in the Department of Biotechnology and Innovation Projects of All-Russian Research Institute of Vegetable Growing - FGBNU FNTSO branch (Moscow region, Ramensky district, Vereya village) in a protected and open ground during 20142019.

In order to study the elemental composition of garlic cloves, 24 samples of spring and winter garlic were used. These samples were grown in various soil and climatic conditions, in particular, in the Voronezh, Moscow, Tver regions, Kabardino - Balkaria, Altai Mountains, and in mountains of Shandong province (China).

At least 10 cloves isolated from various bulbs were used For analysis of each sample.

The analysis was performed according to the method of Dr. Skalnoy at OOO "Micronutrients". The mass spectral analysis was implemented, using the NexION 300D device (PerkinElmerInc., Shelton, CT 06484, USA). This device is equipped with a gasfilled cell of the DRC system and a FAST seven-port metering valve, as well as with ESISCDX4 autosampler (Elemental Scientific Scient., Omaha, NE 68122, USA).

\section{Research results and discussion}

Analyzing the scientific literature and the obtained data showed that the studied garlic cloves contain about $4000 \mathrm{mg} / \mathrm{kg}$ of potassium in terms of dry matter, which is $48.1 \%$ of the mass of all elements contained in the cloves. Moreover, cloves contain about 1500 $\mathrm{mg} / \mathrm{kg}$ of phosphorus (18.3\%), about $1400 \mathrm{mg} / \mathrm{kg}$ of sulfur $(17.2 \%)$, almost $900 \mathrm{mg} / \mathrm{kg}$ of calcium (10.7\%), nearly $300 \mathrm{mg} / \mathrm{kg}$ of magnesium (3.6\%) and about $100 \mathrm{mg} / \mathrm{kg}$ of sodium $(1.3 \%)$ (Table 2). Furthermore, there is a published data showing that garlic can accumulate up to $105595 \mathrm{mg} / \mathrm{kg}$ of potassium in the cloves [6].

The content of other chemical elements was less and amounted to the following values: $20 \mathrm{mg} / \mathrm{kg}$ of silicon $(0.24 \%), 16 \mathrm{mg} / \mathrm{kg}$ of ferrum $(0.20 \%), 14 \mathrm{mg} / \mathrm{kg}$ of zinc $(0.17 \%)$.

The content of manganese, aluminum, copper and boron was even lower and amounted to $6.9 \mathrm{mg} / \mathrm{kg}(0.084 \%), 3.0(0.04 \%), 3.0(0.04 \%)$ and $1.8 \mathrm{mg} / \mathrm{kg}(0.02 \%)$, respectively. Moreover, as noted by Mardomi R. (2017), the manganese content can reach up to 16720 $\mathrm{mg} / \mathrm{kg}[9]$.

The chromium content was $0.22 \mathrm{mg} / \mathrm{kg}(0.003 \%), 0.16 \mathrm{mg} / \mathrm{kg}$ of nickel $(0.002 \%), 0.10$ $\mathrm{mg} / \mathrm{kg}$ of selenium $(0.001 \%), 0.043 \mathrm{mg} / \mathrm{kg}$ of cadmium $(0.0005 \%), 0.042 \mathrm{mg} / \mathrm{kg}$ of cobalt $(0.0005 \%), 0.033 \mathrm{mg} / \mathrm{kg}$ of iodine $(0.0004 \%), 0.025 \mathrm{mg} / \mathrm{kg}$ of lithium $(0.0003 \%), 0.021$ $\mathrm{mg} / \mathrm{kg}$ of vanadium $(0.0003 \%), 0.02 \mathrm{mg} / \mathrm{kg}$ of germanium $(0.0002 \%)$ and $0.013 \mathrm{mg} / \mathrm{kg}$ of lead $(0.0002 \%)$. The mercury's content was lowest and equaled $0.0043 \mathrm{mg} / \mathrm{kg}(0.00005 \%)$ (Table 2). However, the germanium content in individual samples can reach up to 32.6 $\mathrm{mg} / \mathrm{kg}$ [7]. 
It should be noted that when grown under different conditions, the differences in the contents of such elements as potassium, calcium, sodium, phosphorus, aluminum, chromium, iodine, lithium, manganese, nickel, sulfur, silicon, cadmium, copper, mercury, lead and zinc did not exceed 10 times. The differences in contents of vanadium, boron and cobalt did not exceed more than 20 times, for ferrum and germanium these values were more than 1000 times.

An analysis of the data presented in the table indicates that garlic is a good source of such elements as potassium, calcium, magnesium, phosphorus, ferrum, manganese, selenium, vanadium, copper and zinc. A kilogram of dry matter of garlic contains about the daily human need for these elements.

Table 2. The elemental composition of garlic.

\begin{tabular}{|c|c|c|c|c|c|c|c|c|c|}
\hline \multirow[b]{2}{*}{$\begin{array}{l}\text { Elem } \\
\text { ent }\end{array}$} & \multirow[b]{2}{*}{$\begin{array}{l}\text { The } \\
\text { average } \\
\text { daily } \\
\text { human } \\
\text { require } \\
\text { ment, } \\
\text { mg }[8]\end{array}$} & \multicolumn{5}{|c|}{$\begin{array}{c}\text { The elemental composition of garlic, } \mathrm{mg} / \mathrm{kg} \text { of dry } \\
\text { weight }\end{array}$} & \multicolumn{3}{|c|}{ Generalized data } \\
\hline & & $\begin{array}{l}\text { Mard } \\
\text { omi } \\
\text { R., } \\
2017\end{array}$ & $\begin{array}{c}\text { Sere } \\
\text { din } \\
\text { T.M. } \\
\text { et } \\
\text { al., } \\
2018\end{array}$ & $\begin{array}{l}\text { http://pharmacogn } \\
\text { osy.com.ua }\end{array}$ & $\begin{array}{c}\text { Ha } \\
\text { nds } \\
\text { E.S. } \\
\text { ‘00 } \\
0\end{array}$ & $\begin{array}{c}\begin{array}{c}\text { Resea } \\
\text { rch } \\
\text { data, }\end{array} \\
2017- \\
2018\end{array}$ & $\begin{array}{c}\bar{X}, \\
\text { mg/ } \\
\text { kg } \\
\text { of } \\
\text { dry } \\
\text { mat } \\
\text { ter }\end{array}$ & $\begin{array}{l}\% \text { of } \\
\text { total }\end{array}$ & $\begin{array}{c}\text { the } \\
\text { differ } \\
\text { ence } \\
\text { betwe } \\
\text { en } \\
\text { max } \\
\text { and } \\
\text { min, } \\
\text { times }\end{array}$ \\
\hline K & $\begin{array}{c}2000- \\
5000\end{array}$ & 4010 & $\begin{array}{c}720 . \\
8\end{array}$ & 4010.0 & $\begin{array}{c}6 \\
200\end{array}$ & $\begin{array}{c}4 \\
703.8\end{array}$ & $\begin{array}{l}392 \\
8.9\end{array}$ & 48.1 & 6.5 \\
\hline $\mathrm{P}$ & $\begin{array}{l}700- \\
1500\end{array}$ & 1530 & $\begin{array}{c}264 . \\
8\end{array}$ & 1530.0 & $\begin{array}{c}170 \\
0\end{array}$ & $\begin{array}{c}2449 . \\
0\end{array}$ & $\begin{array}{l}149 \\
4.8\end{array}$ & 18.3 & 9.2 \\
\hline $\mathrm{S}$ & & 700 & - & 2114 & - & - & $\begin{array}{l}140 \\
7.0\end{array}$ & 17.2 & 3.0 \\
\hline $\mathrm{Ca}$ & 1000 & 1810 & $\begin{array}{c}318 . \\
4\end{array}$ & 1810.0 & 190 & 259.6 & $\begin{array}{c}877 . \\
6\end{array}$ & 10.7 & 9.5 \\
\hline $\mathrm{Mg}$ & $300-400$ & 250 & $\begin{array}{c}414 . \\
9\end{array}$ & 250.0 & 250 & 311.1 & $\begin{array}{c}295 . \\
2\end{array}$ & 3.6 & 1.7 \\
\hline $\mathrm{Na}$ & 550 & 170 & 32.8 & 170.0 & - & 55.9 & $\begin{array}{c}107 . \\
2\end{array}$ & 1.3 & 5.2 \\
\hline $\mathrm{Si}$ & 50.0 & - & 17.1 & 25.6 & - & 16.8 & 19.8 & 0.24 & 1.5 \\
\hline $\mathrm{Fe}$ & $10-15$ & - & 22.2 & 0.02 & 19.0 & 23.3 & 16.1 & 0.20 & 1165 \\
\hline $\mathrm{Zn}$ & $7-12$ & - & 9.8 & 11.6 & 21.5 & 14.2 & 14.3 & 0.17 & 2.2 \\
\hline $\mathrm{Mn}$ & $2.0-5.0$ & 16720 & 5.3 & 12.4 & 6 & 4.0 & 6.9 & 0.08 & 3.1 \\
\hline $\mathrm{Cu}$ & $1.0-3.0$ & - & 2.0 & 2.1 & 5.8 & 2.1 & 3.0 & 0.04 & 2.9 \\
\hline $\mathrm{Al}$ & & - & 3.7 & 4.5 & - & 0.7 & 3.0 & 0.04 & 6.4 \\
\hline B & 3.0 & - & - & 0.31 & - & 3.32 & 1.8 & 0.02 & 10.7 \\
\hline $\mathrm{Cr}$ & $0.03-0.1$ & - & - & 0.40 & - & 0.04 & 0.22 & $\begin{array}{c}0.00 \\
3\end{array}$ & 10.0 \\
\hline $\mathrm{Ni}$ & 40 & - & - & 0.17 & - & 0.15 & 0.16 & $\begin{array}{c}0.00 \\
2\end{array}$ & 1.1 \\
\hline $\mathrm{Se}$ & $\begin{array}{l}0.05- \\
0.07\end{array}$ & - & - & 0.14 & - & 0.06 & 0.10 & $\begin{array}{c}0.00 \\
1\end{array}$ & 2.3 \\
\hline Co & 5.0 & - & - & 0.08 & - & 0.004 & $\begin{array}{c}0.04 \\
2\end{array}$ & $\begin{array}{c}0.00 \\
05\end{array}$ & 20.0 \\
\hline $\mathrm{Cd}$ & & - & 0.03 & - & - & 0.056 & $\begin{array}{c}0.04 \\
3\end{array}$ & $\begin{array}{c}0.00 \\
05\end{array}$ & 1.9 \\
\hline I & $0.15-0.2$ & - & - & 0.06 & - & 0.006 & $\begin{array}{c}0.03 \\
3\end{array}$ & $\begin{array}{c}0.00 \\
04\end{array}$ & 10.0 \\
\hline
\end{tabular}




\begin{tabular}{|l|c|c|c|c|c|c|c|c|c|}
\hline $\mathrm{Li}$ & 0.25 & - & - & 0.03 & - & 0.02 & $\begin{array}{c}0.02 \\
5\end{array}$ & $\begin{array}{c}0.00 \\
03\end{array}$ & 1.5 \\
\hline $\mathrm{V}$ & 0.025 & - & - & 0.04 & - & 0.003 & $\begin{array}{c}0.02 \\
1\end{array}$ & $\begin{array}{c}0.00 \\
03\end{array}$ & 13.3 \\
\hline $\mathrm{Ge}$ & & - & 0.03 & 32.6 & - & 0.005 & 0.02 & $\begin{array}{c}0.00 \\
02\end{array}$ & 6520 \\
\hline $\mathrm{Pb}$ & & - & 0.02 & - & - & 0.006 & $\begin{array}{c}0.01 \\
3\end{array}$ & $\begin{array}{c}0.00 \\
0\end{array}$ & 3.3 \\
\hline $\mathrm{Hg}$ & & - & $\begin{array}{c}0.00 \\
\mathrm{Hg}\end{array}$ & - & - & $\begin{array}{c}<0.00 \\
36\end{array}$ & $\begin{array}{c}0.00 \\
43\end{array}$ & $\begin{array}{c}0.00 \\
005\end{array}$ & 1.4 \\
\hline
\end{tabular}

Analyzing the literature data and research results showed that the garlic's elemental composition variability much less depends on the variety than on the growing conditions. In general, the elemental composition varied by 1.1-4.7 times depending on the variety, and by 2.1-57.4 times depending on the growing conditions (Table 3 ). The differences in the iron content change depending on the variety were 1.5 times, and 57.4 times depending on the growing conditions. For copper the values were 1.4 times and 54.0 times, respectively, 1.1 times and 26.8 times for sodium.

Table 3. The elemental composition of garlic, depending on the variety and growing conditions.

\begin{tabular}{|c|c|c|c|c|}
\hline \multirow{2}{*}{ Element } & \multicolumn{4}{|c|}{ The dependence of the elemental composition of garlic } \\
\cline { 2 - 5 } & \multicolumn{2}{|c|}{ on the grade [10] } & $\begin{array}{c}\text { on the growing conditions (research } \\
\text { data, 2017-2018) }\end{array}$ \\
\hline & $\begin{array}{c}\overline{\mathrm{X}}, \mathrm{mg} / \mathrm{kg} \text { of dry } \\
\text { matter }\end{array}$ & $\begin{array}{c}\text { the difference } \\
\text { between max and } \\
\text { min, times }\end{array}$ & $\begin{array}{c}\overline{\mathrm{X}}, \mathrm{mg} / \mathrm{kg} \text { of dry } \\
\text { matter }\end{array}$ & $\begin{array}{c}\text { the difference } \\
\text { between max and } \\
\text { min, times }\end{array}$ \\
\hline $\mathrm{K}$ & $450.5 \pm 31.4$ & 1.1 & $4703.85 \pm 470.25$ & 4.8 \\
\hline $\mathrm{Ca}$ & $198.96 \pm 32.09$ & 1.5 & $259.59 \pm 25.97$ & 17.2 \\
\hline $\mathrm{Mg}$ & $259.26 \pm 37.8$ & 1.2 & $311.06 \pm 31.05$ & 6.9 \\
\hline $\mathrm{Na}$ & $20.54 \pm 2.57$ & 1.1 & $55.94 \pm 5.58$ & 26.8 \\
\hline $\mathrm{P}$ & $165.52 \pm 15.94$ & 1.2 & $2449.0 \pm 244.0$ & 13.6 \\
\hline $\mathrm{Al}$ & $2.27 \pm 3.5$ & 2.5 & $0.687 \pm 0.102$ & 1.4 \\
\hline $\mathrm{Fe}$ & $13.9 \pm 3.26$ & 1.5 & $23.16 \pm 2.30$ & 57.4 \\
\hline $\mathrm{Ge}$ & 0.022 & & $0.0046 \pm 0.0002$ & 2.1 \\
\hline $\mathrm{Mn}$ & $3.30 \pm 0.21$ & 1.3 & $4.03 \pm 0.404$ & 6.9 \\
\hline $\mathrm{Si}$ & $10.7 \pm 1.46$ & 1.6 & $16.76 \pm 1.676$ & 4.4 \\
\hline $\mathrm{Cd}$ & $0.021 \pm 0.07$ & 2.1 & $0.056 \pm 0.006$ & 13.3 \\
\hline $\mathrm{Cu}$ & $1.27 \pm 0.23$ & 1.4 & $2.07 \pm 0.202$ & 54.0 \\
\hline $\mathrm{Pb}$ & $0.0124 \pm 0.0032$ & 4.7 & $0.0064 \pm 0.0012$ & 3.3 \\
\hline $\mathrm{Zn}$ & $6.1 \pm 0.87$ & 1.7 & $14.23 \pm 1.40$ & 8.8 \\
\hline
\end{tabular}

A comparison of the garlic's elemental composition with other essential foods indicates that garlic is characterized by a unique and valuable elemental complex. Garlic is especially valuable regarding potassium, phosphorus, calcium, magnesium, sodium, ferrum, manganese, silicon, zinc and copper contents (Table 4). These elements are of high biological significance for human health [7]. Thus, potassium is responsible for maintaining the composition constancy of the cell and intercellular fluid, maintaining acid-base balance, ensuring intercellular contacts. Potassium also helps ensuring the bioelectrical activity of cells, maintaining neuromuscular excitability and conduction, regulating heart contractions, maintaining a normal level of blood pressure, participating in ensuring the function of kidneys.

Phosphorus contributes to the skeleton development, increases tooth resistance to caries, is necessary for the central nervous system and is involved in intracellular 
metabolism. It is part of nucleic acids and nucleotides (DNA, RNA), participates in the processes of encoding and storing genetic information. Phosphorus compounds are involved in the most important processes of energy exchange. Adenosine triphosphoric acid (ATP) is an accumulator of energy, thinking and mental activity is associated with its transformations, as well as the energy life support of the organism.

Calcium forms the basis of bone tissue, participates in the metabolism, processes of transmitting the nerve impulses, and provides a balance between the excitation and inhibition processes in the cerebral cortex. Moreover, calcium participates in regulating the contractility of skeletal muscles and heart muscles, affects the acid-base balance, the activity of various enzymes, participates in metabolism, hematopoiesis, increases the body's resistance to infections and toxins. It is necessary for the functioning of cell membranes, the work of the nuclear apparatus of the cell, helps to stabilize mast cells and inhibits the release of histamine, thereby reducing the manifestations of allergic reactions, pain and inflammatory processes. It is a factor in blood coagulation, lowers blood cholesterol, and is involved in the formation of the immune response.

Magnesium is a macronutrient and $90 \%$ of modern people suffer from its insufficiency. The physiological purpose of magnesium is due to its participation in a number of important enzymatic processes as a cofactor. Magnesium is a structural component for a significant number of enzymes, in particular ATP-dependent ones. This determines the systemic effect of magnesium on energy processes in all organs and tissues, primarily those that are actively energy-consuming (heart, nervous system, working muscles). This element is involved in protein synthesis, normalizes the function of the kidneys and bile ducts, and has a positive effect on the functioning of the cardiovascular and nervous systems. Magnesium participates in the conversion of creatine phosphate to ATP. It is an anti-stress macronutrient, has a positive effect on the reproductive system.

Sodium is an electrolyte that plays a key role in regulating fluid metabolism and osmotic pressure, the violation of which lead to thirst, dry mucous membranes and swelling of the skin. Sodium has a significant effect on protein metabolism.

In the human body, ferrum is involved in the processes of hematopoiesis, oxygen exchange, as well as in immunobiological and redox reactions. Normal ferrum reserves in the body are 300-1000 mg for adult women and 500-1500 mg for adult men. Many people have a ferrum reserve at the lower limit of normal value. It has been proven that many healthy women actually lack ferrum reserves.

Manganese has a significant effect on the vital activity of living organisms. It belongs to the most important microelements and is a component of many enzymes performing numerous functions in the body, and actively affects the metabolism of proteins, carbohydrates and fats. The ability of manganese to enhance the action of insulin and maintain a certain level of cholesterol in the blood is also considered significant. The body uses fats fuller in the presence of manganese. Manganese is involved in the formation of bone tissue formation and hematopoiesis, ensures the normal functioning of the nervous system, and helps fight allergic reactions and diabetes.

In the human body, silicon is involved in the formation of connective and epithelial tissues, promotes hair and nail growth and stimulates phagocytosis. It is contained in the human body in the form of various compounds that are involved mainly in the formation of solid skeletal parts and tissues. In this case, silicon is necessary to maintain the elasticity of the arteries and plays an important role in preventing the cardiovascular diseases. It prevents the harmful effects of aluminum on the organism, stimulates the activity of the immune system. Silicon slows down the aging process; prevents the penetration of cholesterol into blood plasma and the deposition of lipids on the walls of blood vessels. Moreover, it facilitates the renal excretion of metabolites, foreign and toxic substances; serves as a barrier to the spread of degenerative processes; binds decay products of tumor 
tissues and affects the metabolic processes in red blood cells. The occurrence of many pathological processes, including cancer, atherosclerosis, tuberculosis, diabetes, goiter, some dermatitis, stones in the urinary tract, is often associated with metabolic disorders regarding silicon compounds in the body.

Zinc is a macroelement taking part in protein synthesis, copying of genetic material, hematopoiesis, functioning of the immune and endocrine systems, and acts as a cofactor of several hundreds of zinc-dependent enzymes. Lack of zing leads to growth retardation, dwarfism, delayed puberty, damage to the skin and mucous membranes (dermatitis, baldness, parakeratosis), infertility, increased tumor growth, nail and hair pathology. Zinc is involved in the activity of endocrine glands, it particularly takes part in the synthesis of male hormones, such as testosterone, as well as insulin and growth hormone. Zinc ensures the normal functioning of the prostate and pancreas.

In the human body, copper is involved in the process of tissue respiration, in the anabolism, the synthesis of hemoglobin, pigments of the skin, hair and eyes, affects the functioning of the closed glands. It is included in the structure of cytochrome oxidase and so is necessary for the processes of energy generation in the cell. It plays an important role in the body's antioxidant defense, since together with zinc it is part of the superoxide dismutase structure, which is a tissue antioxidant enzyme. Copper along with zinc are also included in ceruloplasmin, which is an antioxidant protein of blood plasma and has antiinflammatory and antiseptic properties. Copper regulates the exchange of catecholamines, serotonin, tyrosine, melanin, helps the increase of insulin activity and more complete utilization of carbohydrates. Furthermore, it participates in the formation of myelin sheaths of nerves, the degeneration of which leads to multiple sclerosis and other severe disorders of the nervous system.

The indicators for a number of these elements approach to corresponding indicators of meat and fish, which indicates the need for garlic in the diet of vegetarians and for a number of diets providing restriction for meat and fish dishes. Taking into account the high chemical value of this cultivated crop type against the background of low garlic consumption (about $4 \mathrm{~kg}$ per capita on average), it is necessary to develop technologies and methods reducing odor, to expand the range of garlic-containing products and add it to various dishes more often.

Table 4. The content of chemical elements per $100 \mathrm{~g}$ of edible part.

\begin{tabular}{|c|c|c|c|c|c|c|c|c|c|c|c|}
\hline \multirow[b]{2}{*}{$\underset{\text { nt }}{\text { Eleme }}$} & \multicolumn{11}{|c|}{ The content of chemical elements $\mathbf{m g} / \mathbf{1 0 0} \mathrm{g}$ of edible part } \\
\hline & $\begin{array}{c}\text { por } \\
\mathbf{k}\end{array}$ & beef & $\begin{array}{c}\text { fish } \\
\text { (cod } \\
\text { ) }\end{array}$ & $\begin{array}{c}\text { whea } \\
\text { t }\end{array}$ & $\begin{array}{c}\text { ric } \\
\mathrm{e}\end{array}$ & $\begin{array}{c}\text { cor } \\
\mathbf{n}\end{array}$ & $\begin{array}{c}\text { potat } \\
0\end{array}$ & $\begin{array}{c}\text { white } \\
\text { cabbag } \\
\text { e }\end{array}$ & $\begin{array}{c}\text { carro } \\
\text { ot }\end{array}$ & $\begin{array}{c}\text { tomat } \\
\mathbf{0}\end{array}$ & $\begin{array}{c}\text { garli } \\
\text { c }\end{array}$ \\
\hline K & 316 & 355 & 316 & 580 & $\begin{array}{c}34 \\
0\end{array}$ & 330 & $\begin{array}{c}268- \\
421\end{array}$ & 185 & 240 & 290 & 236 \\
\hline $\mathrm{P}$ & 170 & 188 & 208 & 410 & $\begin{array}{c}28 \\
5\end{array}$ & 310 & $57-58$ & 31 & 55 & 26 & 90 \\
\hline $\mathrm{S}$ & 220 & 230 & 200 & & & & & 0.037 & 0.006 & 0.012 & 84 \\
\hline $\mathrm{Ca}$ & 8 & 10.2 & 23 & 60 & 68 & 30 & $10-12$ & 48 & 51 & 14 & 53 \\
\hline $\mathrm{Mg}$ & 27 & 22 & 26 & 180 & 90 & 140 & 23 & 16 & 38 & 20 & 18 \\
\hline $\mathrm{Na}$ & 64.8 & 73 & 98 & & & & $6-28$ & 13 & 15 & 40 & 6.4 \\
\hline $\mathrm{Fe}$ & 1.94 & 2.9 & 0.65 & 6 & - & 2.0 & $\begin{array}{c}0.78- \\
0.90 \\
\end{array}$ & 0.6 & 0.70 & 0.90 & 0.96 \\
\hline $\mathrm{Zn}$ & 2.07 & 3.24 & 1.02 & & & & 0.29 & 0.4 & 0.40 & 0.20 & 0.84 \\
\hline $\mathrm{Mn}$ & $\begin{array}{c}0.02 \\
8 \\
\end{array}$ & $\begin{array}{c}0.03 \\
5 \\
\end{array}$ & $\begin{array}{c}0.08 \\
0 \\
\end{array}$ & 5.5 & 6.0 & 0.6 & 0.15 & 0.17 & 0.20 & 0.14 & 0.42 \\
\hline $\mathrm{Cu}$ & 0.10 & 0.18 & 0.15 & 0.8 & 0.3 & 0.2 & 0.11 & 0.075 & 0.08 & 0.11 & 0.18 \\
\hline $\mathrm{Al}$ & & & & & & & & 0.57 & 0.32 & & 0.18 \\
\hline
\end{tabular}




\begin{tabular}{|c|c|c|c|l|l|l|l|l|l|l|c|}
\hline $\mathrm{B}$ & & & & & & & & 0.2 & 0.20 & & 0.11 \\
\hline $\mathrm{Cr}$ & $\begin{array}{c}0.01 \\
3\end{array}$ & $\begin{array}{c}0.00 \\
8\end{array}$ & & & & & & 0.005 & 0.003 & 0.005 & $\begin{array}{c}0.01 \\
3\end{array}$ \\
\hline $\mathrm{Ni}$ & $\begin{array}{c}0.01 \\
2\end{array}$ & $\begin{array}{c}0.00 \\
9\end{array}$ & & 0.009 & & & & 0.015 & 0.006 & 0.013 & $\begin{array}{c}0.01 \\
0\end{array}$ \\
\hline $\mathrm{Co}$ & $\begin{array}{c}0.00 \\
8\end{array}$ & $\begin{array}{c}0.00 \\
7\end{array}$ & $\begin{array}{c}0.03 \\
1\end{array}$ & & & & & 0.003 & 0.002 & 0.006 & $\begin{array}{c}0.00 \\
2\end{array}$ \\
\hline $\mathrm{I}$ & $\begin{array}{c}0.00 \\
7\end{array}$ & $\begin{array}{c}0.00 \\
7\end{array}$ & $\begin{array}{c}0.13 \\
5\end{array}$ & & & & & 0.003 & 0.005 & 0.002 & $\begin{array}{c}0.00 \\
2\end{array}$ \\
\hline
\end{tabular}

\section{Conclusion}

Garlic is a valuable source of macro- and micronutrients, especially potassium, calcium, magnesium, phosphorus, ferrum, manganese, selenium, vanadium, copper and zinc. The dry matter of garlic contains about $4000 \mathrm{mg} / \mathrm{kg}$ of potassium, about $1500 \mathrm{mg} / \mathrm{kg}$ of phosphorus, nearly $1400 \mathrm{mg} / \mathrm{kg}$ of sulfur, almost $900 \mathrm{mg} / \mathrm{kg}$ of calcium, about $300 \mathrm{mg} / \mathrm{kg}$ of magnesium, about $100 \mathrm{mg} / \mathrm{kg}$ of sodium, $20 \mathrm{mg} / \mathrm{kg}$ of silicon, $16 \mathrm{mg} / \mathrm{kg}$ of ferrum, 14 $\mathrm{mg} / \mathrm{kg}$ of zinc.

The cultivation of garlic in different climatic conditions leads to a significant change in the content of various elements. The content of vanadium, boron and cobalt can vary by 20 times, and the content of ferum and germanium by more than 1000 times.

The variability of the garlic elemental composition much less depends on the variety than on the growing conditions. The elemental composition varies by 1.1-4.7 times depending on the variety, and by 2.1-57.4 times depending on the growing conditions. Differences in ferrum content changes were 1.5 times depending on the variety, and 57.4 times depending on growing conditions. For copper the values were 1.4 times and 54.0 times, respectively, 1.1 times and 26.8 times for sodium.

Garlic is characterized by a unique elemental complex. The indicators for a number of these elements approach to corresponding indicators of meat and fish, which indicates the need for garlic in the diet of vegetarians and for a number of diets providing restriction for meat and fish dishes. Taking into account the high chemical value of this cultivated crop type, it is necessary to develop technologies, methods and recipes, which will lead to an increase in garlic's consumption.

\section{References}

1. M.A. Turan, S. Taban, N. Taban, L.Y. Ersan, Fresenius Environmental Bullet. 26(6), 4292-4298 (2017)

2. A.V. Skal’ny`j, Ximicheskie e lementy`v fiziologii i e`kologii cheloveka (ONIKS 21 vek. M. Mir, Moscow, 2004)

3. A.V. Skal'ny’j, Mikroe 'lementy`v medicine, 5-13 (2018)

4. B.U. Bagudo, O.D. Acheme, Der Chemica Sinica 5(1), 128-134 (2014)

5. M. Sajid, M.S. Butt, A. Shehzad, S. Tanweer, PAK. J. FOOD SCI. 24(2), 108-110 (2014)

6. B.J. Divya, B. Suman, M. Venkataswamy, K. Thyagaraju, International Journal of Current Pharmaceutical Research 9(3), 42-45 (2017)

7. Yu. Abayomi, S.S. Fagbuaro, S.O.K. Fajemilehin, Journal of Bioscience and Biotechnology Discovery 3(5), 105-109 https://doi.org/10.31248/JBBD2018.073 ISSN 2536-7064 
8. http://pharmacognosy.com.ua

9. Dentsche Geselschaft fur Ernahrung - DGF, https://ydoo.info/mikroelementy.html

10. R. Mardomi, IOSR Journal of Applied Chemistry (IOSR-JAC) 10(1.I), 63-66 (2017) DOI: 10.9790/5736-1001016366 www.iosrjournals.org 63

11. T.M. Seredin, A.F. Agafonov, L.I. Gerasimova, A.V. Soldatenko, L.V. Krivenkov, Selekciya chesnoka ozimogo na kachestvo produkcii. Monografiya (Litera, MoscowOmsk, 2018)

12. E.S. Nands, Nutrition in food (Wolters Kluwer Company Lippincott Williams and Wilkins-Philadelphia, 2000)

13. I.M. Skurixina, V.A. Tutel’yana, Ximicheskij sostav pishhevy`x produktov (DeLi print, Moscow, 2002)

14. A.A. Pokrovskogo, Ximicheskij sostav pishhevy`x produktov (Pishhevaya promy`shlennost', Moscow, 1976)

15. Yu.F. Zayas, Kachestvo myasa $i$ myasoproduktov (Legkaya i pishhevaya promy`shlennost', Moscow, 1981) 